\title{
Cell Adhesion Molecule
}

National Cancer Institute

\section{Source}

National Cancer Institute. Cell Adhesion Molecule. NCI Thesaurus. Code C16393.

A diverse family of cell surface and extracellular glycoproteins involved in cell-cell adhesion, cell-extracellular matrix adhesion, recognition, and activation. There are four main classes of cell adhesion molecules: integrins, selectins, cadherins, and immunog lobulin-like adhesion molecules. 